\title{
Social Sustainability of Post-Disaster: How Teachers Enable Primary School Students to Be Resilient in Times of Ranau Earthquake
}

\author{
Soon Singh Bikar ${ }^{1, *}$, Balan Rathakrishnan ${ }^{1}\left(\mathbb{D}\right.$, Mohammad Rahim Kamaluddin ${ }^{2}(\mathbb{D}$, \\ Norruzeyati Che Mohd Nasir ${ }^{3}$ and Mohd Azrin Mohd Nasir ${ }^{3}$ \\ 1 Faculty of Psychology and Education, Universiti Malaysia Sabah, Kota Kinabalu 88400, Malaysia; \\ rbhalan@ums.edu.my \\ 2 Centre for Research in Psychology and Human Well-Being, Faculty of Social Sciences and Humanities, \\ Universiti Kebangsaan Malaysia, Bangi 43600, Malaysia; rahimk@ukm.edu.my \\ 3 School of Applied Psychology, Social Work \& Policy, College of Art and Sciences, Universiti Utara Malaysia, \\ Sintok 06010, Malaysia; zeyati@uum.edu.my (N.C.M.N.); mohdazrin@uum.edu.my (M.A.M.N.) \\ * Correspondence: soonbs@ums.edu.my
}

check for

updates

Citation: Bikar, S.S.; Rathakrishnan,

B.; Kamaluddin, M.R.; Che Mohd

Nasir, N.; Mohd Nasir, M.A. Social

Sustainability of Post-Disaster: How

Teachers Enable Primary School

Students to Be Resilient in Times of

Ranau Earthquake. Sustainability 2021,

13, 7308. https://doi.org/10.3390/

su13137308

Academic Editor: Carlos Salavera

Received: 19 May 2021

Accepted: 17 June 2021

Published: 30 June 2021

Publisher's Note: MDPI stays neutral with regard to jurisdictional claims in published maps and institutional affiliations.

Copyright: (c) 2021 by the authors. Licensee MDPI, Basel, Switzerland. This article is an open access article distributed under the terms and conditions of the Creative Commons Attribution (CC BY) license (https:// creativecommons.org/licenses/by/ $4.0 /)$.

\begin{abstract}
The Ranau Earthquake that struck on 5 June 2015, February 2018, and April 2021, were a new disaster in Sabah and caused many Sabahan to panic. The unpredicted disaster also caused a serious impact on all aspects of life in Sabah. The earthquake has caused severe damage to eight primary schools in the vicinity of the epicenter, although no casualties were reported. However, the disaster has deep passing psychological effects among students. In this study, we examine how the primary school teachers enabled the student to be resilient during and after the disaster. Based on the interviews with 16 primary school students, it was revealed that most of the teachers used WhatsApp to support resilience during and after the earthquake. Interviews with 16 primary school teachers revealed there were two main reasons for them to communicate with students, namely, delivering emotional aid and monitoring their stress. Based on student interviews, five content categories of emotional support were identified: caring, reassuring, emotion sharing, belonging, and distracting. The main contribution of this study is that social media can be used as a spontaneous and proactive tool for supporting the student's resilience during and after the earthquake trauma.
\end{abstract}

Keywords: earthquake; resilience; WhatsApp; emotional support

\section{Introduction}

An earthquake refers to the vibrations experienced by the crust when energy is released due to friction or plate friction. This shock will produce a seismic wave in the form of a circle starting at the center of the quake. It occurs in three stages, namely the initial tremor, the main shake, and the end of the tremors. The stronger the tremors are, the greater the seismic waves will be released and the earthquake phenomenon will become more and more powerful. According to Arbogast and Strahler, the friction between the two plates allows energized energy [1,2]. The accumulated power that cannot be buried again will be released. This causes Earth's crust to vibrate. An earthquake usually occurs along the continental plate and 75\% of earthquakes in the world the effect of the Pacific Api Link. Generally, there are two types of earthquakes that occur which are tectonic and volcanic earthquakes. Tectonic earthquakes occur as a result of sudden energy releases when tectonic plates collide, diverge, and diffuse between one another. Volcanic earthquakes occur as a result of volcanic eruptions that cause magma movement and the breakdown of the rocks in the holes.

Malaysia is one of the world's most strategic geographical locations and is safe from earthquake threats because it is located outside the Circle line [3], which is the main zone of volcanoes and earthquakes. However, Sabah is a state located on the northern portion 
of Borneo and in the region of East Malaysia that has experienced a series of earthquakes which have been impacted by neighboring countries located in the earthquake zone [4]. The summary of earthquake events is as shown in Table 1.

Table 1. Earthquake series in Sabah.

\begin{tabular}{lll}
\hline Years & \multicolumn{1}{c}{ Location } & \multicolumn{1}{c}{ Scale } \\
\hline 1897 & $100 \mathrm{~km}$ outside Sabah & 8.7 Magnitude \\
\hline 1976 & Lahad Datu & 5.6 Magnitude \\
\hline 1989 & Ranau & 5.6 Richter \\
\hline 1991 & Ranau & 5.1 Richter \\
\hline 2005 & Ranau & 4.1 Richter \\
\hline 2005 & East Tawau & 5.8 Richter \\
\hline 2010 & North EastRanau & 2.6 Ritcher \\
\hline 2011 & Lahad Datu & 3.3 Ritcher \\
\hline 2011 & Tongod, Sandakan & 4.0 Ritcher \\
\hline 2012 & Kunak & 3.7 Ritcher \\
\hline 2013 & North coast, Kudat & 3.6 Ritcher \\
\hline 2014 & Banggi Island, Kudat & 4.4 Ritcher \\
\hline 2015 & Ranau & 5.9 Ritcher \\
\hline 2018 & Ranau & 5.8 Ritcher \\
\hline 2021 & Ranau & 5.9 Ritcher \\
\hline
\end{tabular}

Source: [5].

The series of earthquakes in Table 1 shows that Sabah has been subjected to a number of earthquake incidents. However, the earthquake that struck on 5 June 2015 followed by February 2018 and April 2021 were among the largest earthquake disasters in Sabah and caused many Sabahan to panic. The unpredicted disaster also caused a serious impact on all aspects of life in Sabah. The earthquake has caused severe damaged to eight primary schools in the vicinity of the epicenter, although no casualties were reported. However, the disaster has serious passing psychological trauma effects on children's physical health, emotional growth, and academic performance [4].

A school is considered the core of society in many countries and schools play an important role in disaster problems, both in terms of preparedness and post-disaster recovery. Therefore, teachers who teach in schools in earthquake prone countries will take various measures and intervention programs to reduce and maintain stable levels of psychological and behavioral functioning. For instance, teachers in Christchurch, New Zealand, used ICTs and social networks to offer alternative methods of delivering mental health support and enhanced student resilient during and after the 2011 earthquake disaster struck New Zealand [6,7]. In Indonesia and Japan teachers used a variety of networks to stay contact with students and also used mobile and android-based earthquake games to enhance elementary school students' knowledge and resilience to earthquake disaster [8,9]. Similarly, methods were used in China [10], Nepal [11], and Philippines [12]. In addition, a number of researchers have asserted that communication and support between teacher and students after disaster has enhanced the student resiliency [13].

In Malaysia, however, there is still a lack of extant studies exploring how the teachers contact and enable the students to be resilient during and after the earthquake because it is a natural disaster and it is not often that a major disaster occurs in the country [14]. Therefore, the main aim of this study is to explore how the teachers helped to enhance student resiliency after the Ranau Earthquake in 2018. The following specific research questions were posed to address the above aims: 
1. How school teachers contact the students after the earthquake;

2. Why the teachers interact with their students;

3. How the teachers enhance students' resilience after the earthquake;

4. What benefits do students gain through and out of the communication with their teachers?

\section{Literature Review}

\subsection{Norman Garmezy Resilience Theory (NGRT)}

Norman Garmezy is a clinical psychologist and he is often referred to as the founder of resilience research. He is active in the study of mental illness and schizophrenia. However, his research interest has changed to the field of stress resistance, competence, and resilience. Norman Garmezy has determined resilience as, "not necessarily resilience to stress. Rather, resilience is designed to reflect the ability for recovery and adaptive behaviors that may occur after an initial retreat or compilation inability". This theory proposes that protective factors at the individual and family levels and outside the family strongly influence individual resilience [15]. A number of researchers have asserted that the Norman Garmezy Resilience Theory is the one that focuses most directly on resilience research [16,17]. However, there are very limited studies that investigate resiliency of disaster victims by using the NGRT as a theoretical frame work. In the present study, we used NGRT theoretical lenses through which data are analyzed.

\subsection{The Effect of the Earthquake on Students}

Earthquakes are one of nature's most frightening, destructive, and unpredictable phenomena [18]. Traumatic events potentially exert high stress and impact; create unwanted and uncontrollable terror and horror scenes; and results in prolonged modifications in the social and material environment $[19,20]$. Therefore, considerable research has explored the effect of earthquakes on students. For instance, the Marmara earthquake struck in 2011 and resulted in profound cognitive and psychological effects such as trauma, depression, fear, worry, and sadness on school children [21]. In Pohang, South Korea, the moderate earthquake at 5.4 magnitudes struck in 2017 also had a tremendous impact on life, buildings, and other infrastructure. The effects of change among students who survived the disaster experienced changes in emotions and behaviors, poor academic performance, and fracas of social and family institutions [22]. Similarly, a number of studies have demonstrated the effect of earthquakes on emotional behaviors in students in Yunshu, China [23], Lombok Island, Indonesia [24], and Nepal [25]. These effects of the earthquake on students require relevant expertise to restore the victim's mental and emotional health. Scholars suggest that school and teachers should play an important role in helping students overcome psychological problems and in increasing students' resilience during post-disaster recovery [26]. This has inspired many scholars to explore the how teachers who are teaching at earthquake prone countries help students to cope with post-disaster psychological problems and enhance their resilience [6-11]. However, there are very limited studies that investigate the effects of social media on helping students to cope with psychological problems and disaster resilience.

Within the Malaysian context, earthquakes are not a common natural disaster phenomenon. However, the 2015 and 2018 earthquakes caused Malaysians, especially those living in Ranau, to panic because it was the largest earthquake in magnitude. The earthquake caused severe damage on school buildings. In addition, to date, no study has been conducted to explore the effect of earthquakes on students' psychology and how the school and teacher help the students during and after the earthquake. Hence, more research is necessary to examine the effects of the Ranau earthquake on students and how the teacher helped them to cope with the problem. 


\subsection{Interaction between Student and Teacher during and after the Earthquake}

During the event of an earthquake, the importance of communication before and after an earthquake greatly assists teachers and students in knowing the development of events. In this context, the teacher needs to know the factors that occurred to provide a clear explanation to the students. Teachers need to explain or communicate in order to notify his students concerning the events and steps that are necessary/not necessary to be performed after the post-earthquake [7].

Nevertheless, the question arises as to what the best method is for communication with students during and after the earthquake. Researchers have suggested the use of social media technology such as Facebook, WhatsApp, Telegram, Instagram, and WeChat because they are easily accessible, available, and usable channels of communication with their students [27]. In addition, scholars suggest that teachers can use social media not only for organizational purposes but also for psychosocial purposes [28]. Inspired by these suggestions, researchers began to investigate how the social media technology can be leveraged by teachers for psychosocial purposes and findings shows that it is an useful tool for monitoring emotions and stress among high school students [29]. In addition, findings also reveal that social media technology can be used to monitor the wellbeing of cyber bullying and provide psychological assistance to students with special needs [30]. However, there are very limited studies that investigate the leverage of social media technology during and after the earthquake.

A number of studies have demonstrated the enormous advantages of interaction between student and teacher during and after the earthquake. One of the advantages highlighted by previous studies was able to enhance the students' resilience [31] by providing social support to the students. A similar finding [6] reported that the interaction between the teacher and students provide adequate knowledge to the students to ensure that they can cope effectively with a disaster. Another similar study revealed that the interaction between student and teacher during and after the earthquake has distracted their mind from fear of the earthquake and help them to enhance disaster resilience [32]. Although abroad studies have demonstrated that the interaction between teachers and students has a significant effect on students' resilience, in Malaysia, there are very limited studies that investigate the effect of teacher and student interaction during and after the Ranau earthquake.

\section{Methods}

\subsection{Research Design}

This study employed an intrinsic case study research design. The researchers chose to use an instructional case study to gain a deeper understanding of the issues under study [14]. In this context, the researcher wished to gain a deeper appreciation on of why and how the teachers interact with the students after the earthquake disaster. Another aim is to gain deeper understanding on how the teachers help to enhance student resiliency and what are the benefits the student gain through the interaction.

\subsection{Participants}

The information for the present study was gathered after six months with respect to the Ranau earthquake in 2018. A total of 12 primary schools were located in the Ranau District in Sabah. Purposive sampling methods were applied to select eight primary schools that were badly affected by the earthquake in 2015 and 2018. The same sampling methods were applied to select one junior (less than five years teaching in the school) and senior teacher (more than five years teaching in the school) from each school. A total of 16 teachers were interviewed. Purposive sampling methods were also applied to select two students from each primary school. A total 16 students were selected for the interviews. 


\subsection{Teacher Data Collection}

A one-on-one in-depth interview was conducted with 16 primary school teachers in their school meeting rooms. According to Guest, Bunce, and Johnson, in-depth interviews are the best choice for revealing insight into the respondent and to provide a more profound understanding of the respondents' experiences, emotions, and attitude [33-37]. A total of 16 one-to-one interviews were conducted. The interviews were conducted by the trained research assistants for $60 \mathrm{~min}$ to $90 \mathrm{~min}$ and they were audio-taped.

\subsection{Student Data Collection}

The interviews were conducted on a one-to-one basis in the school's administrative meeting room. The venue was chosen because it was cozy, appropriate, and secured from interruptions. A total of 16 interviews were conducted. Each interview session began with a brief description of the structure of the interview to be conducted and ended with the researcher thanking the student for their participation and ensuring them of the confidentiality of their responses. The researcher also assured the students that their responses will be kept confidential. Each interview session took around $50 \mathrm{~min}$ and $60 \mathrm{~min}$ to be conducted and all the sessions were audio-taped.

\subsection{Data Analysis}

The data analysis used in this study was thematic. Clarke and Braun define thematic analysis as a method of identifying and analyzing patterns in qualitative data. According to them, there are six steps involved in thematic analysis which do not necessarily have to be linear [38]. In this study, the researcher collected qualitative data, namely, interview transcriptions and recordings of respondents' responses during the interviews. This was intended to expose researchers directly to raw data; to allow them to read and reread the data (and hear the audio recording data at least once, if applicable); and to record any initial analytical observations. The second step was the coding process. The researchers used open coding to build the categories of code identified in the first phase. All code items were given equal attention during the encoding process. In fact, researchers used NVIVO applications that allowed researchers to generate a lot of initial code for potential themes and patterns by marking and naming text options in each data item. This can help the researcher to understand the problems related to the research question. In the third phase-identifying the theme-all the initial codes built into the open coding process were improved. In the fourth or theme review phase, revisions were made to all the early themes. Particular attention was paid to internal homogeneity (data coherence and meaningfulness in each theme) and external homogeneity (clarity of data between themes). In the penultimate or fifth phase, researchers examined the validity of the themes in the context of the whole set of data by repeating the process of data extraction and theme examination. The researcher ensured that the themes accurately represented the data set by identifying similarities and contrasts between the themes before revising the final set to ensure that they were consistent with the research questions. The results of the analysis are reported in the sixth phase, based on the themes, by referring directly to the data set. Finally, the researcher triangulated the qualitative findings quantitatively to gain a deeper understanding of the overall findings [14].

\section{Results}

\subsection{How School Teachers Contact the Students after the Earthquake}

The student and teacher interview data yielded five main themes, namely WhatsApp, telegram, mobile line, WeChat, and Instagram.

Analysis of teacher and student interview data shown in the Table 2 concluded that 40 percent of teachers contacted students using WhatsApp. The second most dominant method is by using telegrams, followed by telephone lines and text massages. Analysis of interview data with teachers and students also showed that the Instagram method is a relatively rare method used by teachers to contact students. Therefore, the researcher 
concluded that teachers use various methods to contact students after the Ranau earthquake. The method used depends on the type of chat application owned by the students and the internet accessibility.

Table 2. Categories of theme in terms of teachers' contact with the students after the earthquake.

\begin{tabular}{|c|c|c|}
\hline \multicolumn{3}{|c|}{ Student Responses } \\
\hline Theme & Frequent & Example \\
\hline WhatsApp & $39.6 \%$ & $\begin{array}{l}\text { I only have WhatsApp. So the teacher chat with me } \\
\text { via WhatsApps. (Participant } 1 \text { ) }\end{array}$ \\
\hline Telegram & $33.3 \%$ & $\begin{array}{l}\text { Most of the time, my teachers send a massage } \\
\text { through telegram. (Participant 12) }\end{array}$ \\
\hline Mobile line & $12.3 \%$ & $\begin{array}{l}\text { I don't install whats apps and telegram. So the } \\
\text { teacher always call me through direct line. } \\
\text { (Participant 15) }\end{array}$ \\
\hline Text massages & $9.8 \%$ & $\begin{array}{l}\text { Sometime my class teacher used text massages to } \\
\text { stay in touch with me. (Participant } 4 \text { ) }\end{array}$ \\
\hline Instagram & $5.0 \%$ & $\begin{array}{l}\text { Mostly he will contact me through Instagram. } \\
\text { (Participant 8) }\end{array}$ \\
\hline \multicolumn{3}{|c|}{ Teacher Responses } \\
\hline Theme & Frequent & Example \\
\hline WhatsApp & $40.0 \%$ & $\begin{array}{l}\text { Most of my students having WhatsApp. So I keep in } \\
\text { touch with them by send am massage in WhatsApp. } \\
\text { (Teacher } 4 \text { ) }\end{array}$ \\
\hline Telegram & $36.2 \%$ & $\begin{array}{l}\text { I have a WhatsApp chat. But I prefer to chat with my } \\
\text { students via Telegram. (Teacher 14) }\end{array}$ \\
\hline Mobile line & $13.2 \%$ & $\begin{array}{l}\text { A small group of my students living at remote area } \\
\text { and don't have a internet coverage ... I often keep } \\
\text { in touch with them via mobile line. (Teacher 10) }\end{array}$ \\
\hline Text massages & $9.0 \%$ & Sometimes I used text massages. (Teacher 6) \\
\hline Instagram & $1.6 \%$ & I do chat with them by Instagram. (Teacher 15) \\
\hline
\end{tabular}

\subsection{The Reason for Teachers to Interact with Students}

The analysis of the interview data with teachers has resulted in two main themes of the teacher's intention to interact with their students after the earthquake.

\subsubsection{Emotional Support}

According to the teachers, their first motive was to interact with students after the earthquake and to provide emotional support to their students without any personal connections in the classroom.

Teachers believe that they aid in the progression of the students' resolve and provide psychological support in a prompt and unhampered manner. These included sending calming messages which were sent following negative earthquake-related news. More interestingly, online emotional support was found to be a two-way communication between teachers and students. Two of the interview teachers reported that a few of the students were expressing their concerns towards the teacher. For example, one primary school teacher giving an example of the student's concerns:

"Teacher, I heard that our school was badly damaged because of the earthquake. I pray that you are ok and take care." (TS9)

The teachers offered three reasons and purposes behind why they trusted this "reversed" emotional support to be important: (1) It demonstrated a genuine worry for educators in the disguise of the brilliant instructive principle of correspondence (regarding 
others as one would wish to be dealt with); (2) being worried for others may diminish students' own fears; (3) these outflows of concern fortify the common association among instructors and students.

\subsubsection{Observing Distress}

Another intention of communicating by using WhatsApp with their students was to observe the students' distress after the earthquake. A few teachers deciphered their student' quietness on the web as a sign of emotional difficulties:

"Most of the school students expressed their thought and feelings on WhatsApp. It was all there: fears, tensions, adapting techniques. It was accordingly clear that those students, who decide not to take part in the online discussions, are experiencing issues in emotional sharing. So, I have decided to visit their house and contact them personally." (TS4)

Nearly all of the students expressed their thoughts and feeling on WhatsApp. these consists of the following: worries, tension, adapting techniques such as crawling under the table, staying away from the window, and protecting the head with a pillow. It is very clear that students who are not interested in joining online discussion are having a problems with emotional sharing. Thus the decision was made to visit their home.

The analysis of interviews with students has also established two main themes of the teacher intentions to correspond with their students after the earthquake.

\subsubsection{Sharing Emotions}

Analysis of interview data shows that 10 out of 16 students state that one of the main purposes for the teacher to contact the student after the earthquake disaster is to share emotions and feelings. This is because the school pupils felt scared and panicked after the earthquake hit Ranau. For example, student respondent 16 states that:

I know... teacher called me to share my fear with him after the earthquake. This is because earthquakes are rare in my home area left everyone in fears. The teacher also advised me to pray a lot for us to be safe.

Similarly, the statements of respondents 9,12, and 14 shows that the main purpose of teachers calling them is to share emotions after the earthquake. For example, respondent 9 says the following:

Teachers rarely call me after school hours. But after the earthquake, she massages me via what apps frequently. I think teachers want to share with us about the earthquake fears and to ensure we are safe. She always advises me not be afraid about earthquake and pray hard that we all are will be safe.

Respondent 8 elaborated on this by saying:

My class teacher always contacted me using telegram. We always share our fear if about the earthquake we worried if the disaster repeats again. He advises me to stay strong, not to be afraid and pray to God for the safety of all.

\subsubsection{Providing Assistance and Education on How to Deal with Earthquake Disasters}

Fourteen of the sixteen students interviewed stated that the 2018 earthquake also damaged their houses and affected their parents' daily economic activities. Therefore, they were contacted by the teacher to provide basic assistance such as sugar rice, powder milk, sugar, and snacks. The following are some of responses from the student participants: Participant 10 said the following:

My teacher calls and what Apps me every week to ensure me and my family members are having enough food. She also visited my house last week to give us a food basket.

Participants 3, 11, and 15 explained further:

The teacher keeps in touch with us to ensure we have enough food to eat and stay safe. 
Analysis of interview data responses suggest that 10 out of 16 students explained that the teacher contacted the students for the purpose of educating the students in how to deal with earthquake disasters. For example, respondents 8 and 13 stated the following:

My class teacher always contacted me. Sometimes he used what Apps and telegram.

He sends a lot of video and pictures to teach me and my family members how to save themselves in the event of an earthquake.

Triangulation of interview data between teachers and students show that the main purposes for the teacher's contact with the student were to inform, educate, and share feelings while providing emotional support in order to decrease the stress after the earthquake.

\subsection{How the Teachers Enhance Students' Resilience after the Earthquake}

These interview questions were directed to teachers in order to find out how they strived to increase resilience in students. This is because the earthquakes that struck in 2015 and 2018 were the worst earthquakes in Sabah and have damaged school buildings and caused many primary school students to panic and be fearful. Table 2 shows the emerging themes from data analysis of the teacher interviews.

Analysis of the data in the Table 3 shows that 33.3 percent of primary school teachers teaching in the Ranau district gave social support to increase the resilience of students in order to cope with earthquake disasters. This support is provided by contacting students to show the teacher's concern about students and their family safety. The teacher also shared the emotions and fear with the students. Moreover, the second most dominant method used by teachers to enhance the student resilience is by educating the students about earthquakes (30.2 percent). This method is used by teachers to ensure that the primary school students are better prepared for future earthquake disasters.

Table 3. Categories of theme in the teacher's enhancement of students' resilience after the earthquake.

\begin{tabular}{|c|c|c|c|}
\hline Theme & Frequent & Definition & Example \\
\hline Social support & $33.3 \%$ & $\begin{array}{l}\text { Showing interest and concern } \\
\text { about students and their } \\
\text { family safety; sharing stress } \\
\text { and emotion. }\end{array}$ & $\begin{array}{l}\text { I sent a telegram every day to asked about how they } \\
\text { are doing with the family every day to show my } \\
\text { students that I do care and concern about them. } \\
\text { (Teacher 12) }\end{array}$ \\
\hline Knowledge & $30.2 \%$ & $\begin{array}{l}\text { Educate the students about } \\
\text { the scale of earthquake power, } \\
\text { cause of occurrence, and types } \\
\text { of earthquake. }\end{array}$ & $\begin{array}{l}\text { Normally I send a short video or animation cartoon to } \\
\text { my students to educate them about the earthquake. } \\
\text { (Teacher 8) }\end{array}$ \\
\hline Spiritual & $27.7 \%$ & $\begin{array}{l}\text { Performed a prayer according } \\
\text { to their respective religions. }\end{array}$ & $\begin{array}{l}\text { I have created a small What Apps group. We used to } \\
\text { have a prayer according to our respective religions } \\
\text { every day at } 6 \text { pm for ten minutes. (Teacher 9) }\end{array}$ \\
\hline Distraction & $8.8 \%$ & $\begin{array}{l}\text { Humorous and entertaining } \\
\text { content to distracts students } \\
\text { from the pressures } \\
\text { earthquake disaster. }\end{array}$ & $\begin{array}{l}\text { I strongly believed the students are very stress and } \\
\text { confuse about the earthquake. So I send humorous } \\
\text { video or create a joke when I call them. Sometimes we } \\
\text { share a joke and laughing a lot. This is important to } \\
\text { distract their mind from the disaster. }\end{array}$ \\
\hline
\end{tabular}

The data in the table to indicates $27.7 \%$ of teachers also used spiritual methods to enhance the resilience of the students. For example, teachers performed a prayer according to their beliefs and religion with respect to the students. Data analysis showed that a small number of primary school teachers (8.8 percent) often communicates with students and insert elements of humor to distract students from the pressures and fear of earthquake disaster.

The above findings indicated primary school teachers have played an important role and have used various methods to enhanced the resilience of students in order to cope with the earthquake that struck at Ranau. 


\subsection{Student Perspectives on the Benefit of Communication with Their Teachers}

Ten of the student participants reported that the communication with their teacher made them feel that the teachers care for their emotional state during and after the earthquake. For example, participant 8 said the following:

"I had a more grounded suspicion that all is well and good since I realized that the teacher was caring and thinking about us." (Participant 8)

The respondent elaborated further that the conversations with the teacher act as an interference that assists them in diverting their attention from the negative experiences, which helped the students in coping with the situation by taking their mind off the stressful events.

Another Student mentioned that having communication interaction with their teacher acts as a platform for emotional sharing. Students reported that their teachers were available figures with whom they could express their fears and share their distress.

Another student explained that the conversation with their teacher is a stage for passionate sharing. Students detailed that their teachers were accessible figures with whom they could share their feelings of dread and be offered shelter from distress.

\section{Conclusions and Discussion}

Earthquake disasters potentially exert high stress and impact, create unwanted and uncontrollable terror and horror scenes, and induce psychological effects in every stratum of society. Thus, this study aims to investigate how teachers supported primary school students' resilience after the Ranau earthquake. The analysis of the teachers and students interview data revealed that tele-communication tools such as WhatApps, telegrams, Instagram, and text messages are the main mediums for teachers to communicate with their students. This finding cannot be compared with the results of other studies because there are very limited studies that has investigated how the school teacher stays in contact with their students to provide psychological support after the earthquake. However, several previous studies have reported that most of the teacher used social media in times of war and earthquake to communicate with their students [12,13]. A possible explanation for the findings is that the teachers are more comfortable using social media to interact because it is easy, fast, and safe for them to connect stay connected with their students. These views are supported by the Winarni [7] findings, which showed that social media is an important medium and is offered as an alternative medium in the interaction with students after the earthquake.

Another important finding from the data obtained from the teacher and student interviews revealed that the main reasons for the teacher to interact with students after the earthquake were for emotional support, observing distress, providing assistance, and educating the students on how to deal with earthquake disasters. The data from student interviews showed that the teachers prefer to use WhatsApp, tele-gram, and text messages to contact students for emotional support. The student interviews also revealed that the emotional support was delivered by showing that the teachers cared for the students' prosperity, by expressing consolation, by sharing feelings and providing feelings of inclusion, and by diverting students from unpleasant considerations and occasions.

The findings of the current study suggest that the primary school teachers gave social support by showing interest and concern about students and their family safety and sharing stress and emotion to enhance student resilience. In addition, the teacher also uses social media to educate the students about the earthquake disaster and the use of humorous content distracts students from the pressures of earthquake disaster. The student interviews revealed that one of the benefits in communicating with their teacher was to make them feel that the teachers care for their emotional state during and after the earthquake. It also offers a platform for emotional sharing and diverts their attention from negative experiences. This finding is in agreement with studies by Winarni [9] and Egargo [12].

In summary, the essential commitment of the present study is to provide information to the literature on students' resilience during a traumatic situation and the teacher's 
psychosocial role in them. Formal school-based trauma program for reinforcing students resilience traditionally envisions the teacher's role as a part of the recovery procedure and after the occurrence of a traumatic occasion $[10,11]$. This study also discovers that teachers unexpectedly offer constant interventions by using WhatsApp during the traumatic event without any formal guidance to conduct such actions. Another contribution of the present study is to the rising literature on the usage of social media in times of massive-scale disasters. This specific literature has already demonstrated the benefits of information sharing in real-time [39]. For instance, using Facebook enabled university officers to coordinate a response to an earthquake disaster [35,40]. The present study broadens past findings, which demonstrates another capability of web-based social networking in the midst of emergencies to be more specialized in social-emotional support and to help students enhance their resilience $[29,41]$.

Author Contributions: Conceptualization, S.S.B.; methodology, S.S.B.; validation, M.R.K.; formal analysis, S.S.B.; investigation, N.C.M.N.; resources, S.S.B.; data curation, S.S.B.; writing-original draft preparation, S.S.B.; writing-review and editing, B.R.; visualization, B.R.; supervision, S.S.B.; project administration, M.A.M.N. All authors have read and agreed to the published version of the manuscript.

Funding: This research received no external funding.

Institutional Review Board Statement: Not Applicable.

Informed Consent Statement: Informed consent was obtained from all subjects involved in the study.

Data Availability Statement: Not applicable.

Acknowledgments: The authors appreciate the teachers and students who participated in this research.

Conflicts of Interest: The authors declare no conflict of interest.

\section{References}

1. Arbogast, A.F. Discovering Physical Geography; Michigan State University: East Lansing, MI, USA, 2014.

2. Strahler, A.H. Introducing Physical Geography, 6th ed.; Wiley: Hoboken, NJ, USA, 2013.

3. Tongkul, F. Ranau Earthquake Strongest Since 1976: Professor Dr. Felix Tongkul Explains What Happened. In New Sabah Times; Inna Kinabalu Sdn. Bhd.: Kota Kinabalu, Malaysia, 2015; p. 4.

4. Sintang, S.; Kamu, A.; Sudirman, F. Kesedaran Beragama Masyarakat Kundasang dan Ranau Kesan daripada Bencana Gempa Bumi. J. Perad. 2021, 13, 23-45.

5. Malaysian Meteorological Department. Seismic and Tsunami Hazards and Risks Study in Malaysia; MOSTI: Kuala Lumpur, Malaysia, 2019.

6. Bateman, A.; Robinson, P. The Christchurch earthquake: Lessons from the real-life experiences of early childhood teachers. J. Early Child. Teach. Educ. 2020, 41, 325-337. [CrossRef]

7. Baytiyeh, H. Online learning during post-earthquake school closures. Disaster Prev. Manag. 2018, 27, 215-227. [CrossRef]

8. Shiwaku, K.; Ueda, Y.; Oikawa, Y.; Shaw, R. School disaster resilience assessment in the affected areas of 2011 East Japan earthquake and tsunami. Nat. Hazards 2016, 82, 333-365. [CrossRef]

9. Winarni, E.W.; Purwandari, E.P.; Wachidi, W. The effect of android-based earthquake game toward Bengkulu City elementary school student's knowledge about earthquake disaster preparedness. J. Phys. Conf. Ser. 2021, 1731, 012090. [CrossRef]

10. Xin, Y.; Liu, C.; Peng, X.; Fu, H.; Li, L. How Resilience and Social Support Promote Post-Traumatic Growth after Wenchuan Earthquake: An Integrated Perspective. Res. Sq. 2021, 14, 166-180. [CrossRef]

11. Shrestha, N.; Gopal, B. Psychological Problems among Children Three Years after the Earthquake in Nepal. J. Indian Assoc. Child Adolesc. Ment. Health 2021, 17, 12-34, ISSN 0973-1342.

12. Egargo, F.J.; Pacoma, A.J. The Role of Social Networks in Children's Psychosocial Resilience: A Case Study in the Countryside. Countrys. Dev. Res. J. 2020, 8, 24-34.

13. Rosenberg, H.; Ophir, Y.; Asterhan, C.S. A virtual safe zone: Teachers supporting teenage student resilience through social media in times of war. Teach. Teach. Educ. 2018, 73, 35-42. [CrossRef]

14. Bikar, S.S.; Zulfhıkar, R.; Rathakrishnan, B. Analyze the Conceptual Understanding of Earthquakes among Geography Teachers in Ranau, Sabah. Rev. Int. Geogr. Educ. Online 2021, 11, 429-448. [CrossRef]

15. Shean, M. Current Theories Relating to Resilience and Young People; Victorian Health Promotion Foundation: Melbourne, VIC, Australia, 2015. 
16. Buzzanell, P.M.; Houston, J.B. Communication and resilience: Multilevel applications and insights-A Journal of Applied Communication Research forum. J. Appl. Commun. Res. 2018, 46, 1. [CrossRef]

17. Masten, A.; Best, K.; Garmezy, N. Resilience and development: Contributions from the study of children who overcome adversity. Dev. Psychopathol. 1990, 2, 425-444. [CrossRef]

18. Hadfield, K.; Ungar, M. Family resilience: Emerging trends in theory and practice. J. Fam. Soc. Work 2018, 21, 81-84. [CrossRef]

19. Amanat, N.; Khankeh, H.; Hosseini, M.; Mohammadi, F.; Sadeghi, A.; Aghighi, A. The Effect of Earthquake Preparedness Training to Male High School Students on Families' Preparedness in Eshtehard City in 2010-2011. Sci. J. Rescue Relief 2013, 5, 27-39. Available online: https: / / www.sid.ir/en/journal/ViewPaper.aspx?id=461556 (accessed on 7 June 2021).

20. Felix, E.; Hernández, L.A.; Bravo, M.; Rafael Ramirez, R.; Jose Cabiya, J.; Canino, G. Natural Disaster and Risk of Psychiatric Disorders in Puerto Rican Children. J. Abnorm. Child Psychol. 2011, 39, 589-600. [CrossRef]

21. Sahin, N.H.; Yilmaz, B.; Batigun, A. Psychoeducation for Children and Adult after Marmara Earthquake: An Evaluation Study. Traumatology 2011, 17, 41-49. Available online: https:/ / www.sagepub.com (accessed on 2 June 2021). [CrossRef]

22. Pfefferbaun, B.; Jacob, A.K.; Van Horn, R.L.; Houston, J.B. Effects of Displacement in Children Exposed to Disasters. Curr. Psychiatry Rep. 2016, 18, 71. [CrossRef]

23. Liu, X.; Tang, B.; Zhao, F.; Xue, C.; Dong, J.; Zhang, L. Post-traumatic positive and negative psychological changes experienced by child and adolescent earthquake survivors in remote rural western China: A cross-sectional study six years after the Yushu earthquake. Psychol. Health Med. 2021, 26, 184-195. [CrossRef]

24. Rusmini, L.W.A.; Hariawan, H. Post-earthquake quality of life among students. Int. J. Public Health 2020, 9, 71-75.

25. Dhital, R.; Shibanuma, A.; Miyaguchi, M.; Kiriya, J.; Jimba, M. Effect of psycho-social support by teachers on improving mental health and hope of adolescents in an earthquake-affected district in Nepal: A cluster randomized controlled trial. PLoS ONE 2019, 14, e0223046. [CrossRef]

26. Mutch, C. The role of schools in helping communities copes with earthquake disasters: The case of the 2010-2011 New Zealand earthquakes. Environ. Hazards 2018, 17, 331-351. [CrossRef]

27. Asterhan, C.S.; Bouton, E. Teenage peer-to-peer knowledge sharing through social network sites in secondary schools. Comput. Educ. 2017, 110, 16-34. [CrossRef]

28. Asterhan, C.S.; Rosenberg, H. The promise, reality and dilemmas of secondary school teacher-student interactions in Facebook: The teacher perspective. Comput. Educ. 2015, 85, 134-148. [CrossRef]

29. Ophir, Y.; Asterhan, C.S.; Schwarz, B.B. Unfolding the notes from the walls: Adolescents' depression manifestations on Facebook. Comput. Hum. Behav. 2017, 72, 96-107. [CrossRef]

30. Cho, S.E.; Jung, K.; Park, H.W. Social media use during Japan's 2011 earthquake: How Twitter transforms the locus of crisis communication. Media Int. Aust. 2013, 149, 28-40. [CrossRef]

31. Mooney, M.; Tarrant, R.; Paton, D.; Johnston, D.; Johal, S. The school community contributes to how children cope effectively with a disaster. Pastor. Care Educ. 2021, 39, 24-47. [CrossRef]

32. Guest, G.; Bunce, A.; Johnson, L. How Many Interviews are Enough? An Experiment with Data Saturation and Variability. Field Methods 2006, 18, 59-82. [CrossRef]

33. Bikar, S.S.; Sharif, S.; Talin, R.; Rathakrishnan, B. Students' Perceptions about the Use of Minimalist Robotic Games in Geography Education. Rev. Int. Geogr. Educ. Online 2020, 10, 584-595.

34. Rathakrishnan, B.; Molugulu, N.; Parasuraman, B.; Narasappa, K. The Relationship of Stress, Alcoholism and Sexual Behavior with Mental Health among Secondary School Students: A Study in Sabah, Malaysia. Eur. J. Soc. Sci. 2012, 31, 376-383.

35. Rathakrishnan, B.; George, S. Gambling in Malaysia: An Overview. BJPsych Int. 2021, 18, 32-34. [CrossRef]

36. Rathakrishnan, B.; Samsudin, A.R.; Singh, S.; Juliana, J. Job Preferences among Marginalised and Non-Marginalised Youths: A Multi-Ethnic Study in Sabah. Pertanika. J. Soc. Sci. Hum. 2017, 25, 55-66.

37. Rathakrishnan, B.A.; Bikar Singh, S.S.; Kamaluddin, M.R.; Ghazali, M.F.; Yahaya, A.; Mohamed, N.H.; Krishnan, A.R. Homesickness and Socio-Cultural Adaptation towards Perceived Stress among International Students of a Public University in Sabah: An Exploration Study for Social Sustainability. Sustainability 2021, 13, 4924. [CrossRef]

38. Clarke, V.; Braun, V. Teaching thematic analysis: Overcoming challenges and developing strategies for effective learning. Psychologist 2013, 26, 120-123.

39. Palen, L.; Vieweg, S.; Liu, S.B.; Hughes, A.L. Crisis in a Networked World: Features of Computer-Mediated Communication in the April 16, 2007, Virginia Tech Event. Soc. Sci. Comput. Rev. 2009, 27, 467-480. [CrossRef]

40. Wolmer, L.; Hamiel, D.; Barchas, J.D.; Slone, M.; Laor, N. Teacher-Delivered Resilience-Focused Intervention in Schools with Traumatized Children Following the Second Lebanon War. J. Trauma Stress 2011, 24, 309-316. [CrossRef]

41. Ophir, Y. SOS on SNS: Adolescent Distress on Social Network Sites. Comput. Hum. Behav. 2017, 68, 51-55. [CrossRef] 